\title{
ANALISIS FUNGSI KOGNITIF PADA LANSIA DITINJAU DARI JENIS KELAMIN, RIWAYAT PENDIDIKAN, RIWAYAT PENYAKIT, AKTIVITAS FISIK, AKTIVITAS KOGNITIF, DAN KETERLIBATAN SOSIAL
}

\author{
Arti Febriyani Hutasuhut ${ }^{1}$, Marisa Anggraini ${ }^{2}$, Reza Angnesti ${ }^{3}$ \\ 1,2,3Program Studi Pendidikan Dokter Universitas Malahayati, email: artifebriyani@gmail.com
}

\begin{abstract}
ANALYSIS OF COGNITIVE FUNCTIONS IN ELDERLY IN TERMS OF GENDER, EDUCATION HISTORY, DISEASE HISTORY, PHYSICAL ACTIVITY, COGNITIVE ACTIVITIES, AND SOCIAL ENGAGEMENT
\end{abstract}

One of the disorders caused by degeneration in the elderly is cognitive impairment This study aims to determine the factors that influence cognitive function in the elderly in the work area of the Kedaton Bandar Lampung Health Center in 2018. This research is an analytical survey with a cross-sectional approach. The research subjects were 107 elderly people living in the working area of the Kedaton Health Center in Bandar Lampung. Data in this study were obtained through interviews using questionnaires, social disengagement scale, and MMSE. Data analyzed using chi-square test. The results showed that there was a significant relationship between education, history of illness, physical activity, cognitive activity, and social involvement with cognitive function, whereas for sex, no significant relationship was found with cognitive function.

Keywords: Cognitive Function, Gender, Educational History, History of Illness, Physical Activity, Cognitive Activity, Social Engagement, Elderly

Salah satu gangguan akibat degenerasi pada lansia yaitu gangguan kognitif. Penelitian ini bertujuan untuk mengetahui faktor-faktor yang mempengaruhi fungsi kognitif pada lansia di wilayah kerja Puskesmas Kedaton Bandar Lampung tahun 2018. Penelitian ini merupakan survey analitik dengan pendekatan cross-sectional. Subyek penelitian adalah 107 orang lansia yang tinggal di wilayah kerja Puskesmas Kedaton Bandar Lampung. Data dalam penelitian ini diperoleh melalui wawancara menggunakan kuesioner, skala social disengagement, dan MMSE. Analisis data menggunakan uji chi-square. Hasil penelitian menunjukan bahwa terdapat hubungan yang signifikan antara pendidikan, riwayat penyakit, aktivitas fisik, aktivitas kognitif, dan keterlibatan sosial dengan fungsi kognitif, sedangkan untuk jenis kelamin, tidak ditemukan hubungan signifikan dengan fungsi kognitif.

Kata Kunci : Fungsi Kognitif, Jenis Kelamin, Riwayat Pendidikan, Riwayat Penyakit, Aktivitas Fisik, Aktivitas Kognitif, Keterlibatan Sosial, Lansia

\section{PENDAHULUAN}

Keberhasilan pembangunan berbagai bidang terutama bidang kesehatan menyebabkan terjadinya peningkatan Usia Harapan Hidup (UHH) penduduk dunia terutama Indonesia. Sejak tahun 2004 sampai 2015, usia harapan hidup Indonesia meningkat dari 68,6 tahun menjadi 70,8 tahun dan proyeksi tahun 2030 sampai tahun 2035 mencapai 72,2 tahun (Kemenkes, 2016).
Berdasarkan hasil Survey Sosial Ekonomi Nasional (Susenas) tahun 2014, jumlah lansia di Indonesia mencapai 20,24 juta orang atau sekitar 8,03\% dari seluruh penduduk Indonesia (Kemenkes, 2016). Menurut World Health Organisation (WHO), yang dimaksud dengan Lanjut Usia (lansia) adalah seseorang yang telah mencapai usia 60 tahun ke atas.

Peningkatan populasi lansia mengakibatkan terjadinya transisi epidemiologi, yaitu 


\section{ANALISIS FUNGSI KOGNITIF PADA LANSIA DITINJAU DARI JENIS KELAMIN, RIWAYAT PENDIDIKAN, RIWAYAT PENYAKIT, AKTIVITAS FISIK, AKTIVITAS KOGNITIF, DAN KETERLIBATAN SOSIAL}

bergesernya pola penyakit dari infeksi dan gangguan gizi menjadi penyakit-penyakit degeneratif seperti diabetes, hipertensi, neoplasma, dan penyakit jantung koroner. Gangguan akibat penurunan fungsi lainnya yang sering terjadi pada lansia adalah berhubungan dengan fungsi kognitif (Mardiyanto, Jahja, dan Limyati, 2017).

Fungsi kognitif merupakan fungsi utama untuk memelihara peran dan interaksi yang adekuat dalam lingkungan sosial. Kemunduran fungsi kognitif selanjutnya akan mempengaruhi pola interaksi lansia dengan lingkungan tempat tinggal, dengan anggota keluarga lain, juga pola aktivitas sosialnya sehingga akan menambah beban keluarga, lingkungan dan masyarakat (Wreksoatmodjo, 2014). Penurunan fungsi kognitif dapat dipengaruhi oleh berbagai faktor, baik dari individu maupun lingkungan. Faktor individu meliputi usia, jenis kelamin, tingkat pendidikan, faktor genetik, dan riwayat penyakit. Sedangkan faktor lingkungan meliputi hubungan/keterlibatan sosial (social engagement) dan aktivitas, baik aktivitas fisik maupun aktivitas kognitif (Wreksoatmodjo, 2016).

Penanganan masalah ini seharusnya dimulai sedini mungkin, berupa pencegahan atau upaya mempertahankan fungsi kognitif di kalangan lansia. Salah satu upaya yang dapat dilakukan yaitu dengan mengidentifikasi dan mengendalikan faktor-faktor yang dapat mempengaruhi fungsi kognitif pada lansia. Berdasarkan hal tersebut maka penulis tertarik untuk melakukan penelitian mengenai fungsi kognitif pada lansia ditinjau dari jenis kelamin, riwayat pendidikan, riwayat penyakit, aktivitas fisik, aktivitas kognitif, dan keterlibatan sosial.

\section{METODE}

Jenis penelitian ini termasuk penelitian analitik dengan pendekatan cross sectional yaitu suatu penelitian untuk mempelajari dinamika hubungan antara faktor-faktor resiko dengan efek, dengan cara pendekatan, observasi atau pengumpulan data sekaligus pada suatu saat (Notoatmodjo, 2012). Populasi dalam penelitian ini adalah lansia berusia $\geq 60$ tahun yang bertempat tinggal di wilayah kerja Puskesmas Kedaton Bandar Lampung.. Pengambilan sampel menggunakan simple random sampling dengan teknik penentuan sampel berdasarkan kriteria-kriteria tertentu, didapatkan sampel sebanyak 107 responden. Data dalam penelitian ini diperoleh melalui hasil wawancara berdasarkan kuesioner karakteristik responden, indeks social disengagement untuk mengukur keterlibatan sosial lansia, serta Mini Mental State Examination (MMSE) untuk menilai fungsi kognitif pada lansia. Data dianalisis dengan menggunakan uji Chi square.

Arti Febriyani Hutasuhut, Program Studi Pendidikan Dokter Universitas Malahayati, email: artifebriyani@gmail.com

Marisa Anggraini, Program Studi Pendidikan Dokter Universitas Malahayati

Reza Angnesti, Program Studi Pendidikan Dokter Universitas Malahayati 


\section{ANALISIS FUNGSI KOGNITIF PADA LANSIA DITINJAU DARI JENIS KELAMIN, RIWAYAT PENDIDIKAN, RIWAYAT PENYAKIT, AKTIVITAS FISIK, AKTIVITAS KOGNITIF, DAN KETERLIBATAN SOSIAL}

HASIL

\section{Analisis Univariat}

Analis univariat menggambarkan distribusi frekuensi dari tiap variabel-variabel penelitian, baik variabel bebas maupun variabel terikat. Beberapa variabel yang dianalisis dalam penelitian ini meliputi fungsi kognitif, jenis kelamin, tingkat pendidikan, riwayat penyakit, aktivitas fisik, aktivitas kognitif dan keterlibatan sosial. Hasil dari tiap variabel ini ditampilkan dalam bentuk tabel distribusi frekuensi berikut ini:

Tabel 1

Distribusi Frekuensi Responden Berdasarkan Jenis Kelamin

\begin{tabular}{ccc}
\hline Jenis Kelamin & Frekuensi & Persentase $(\%)$ \\
\hline Perempuan & 79 & 73,8 \\
Laki-laki & 28 & 26,2 \\
\hline Total & 107 & 100
\end{tabular}

Berdasarkan tabel 1 diatas, dapat diketahui responden yang berjenis kelamin laki-laki sebanyak 28 orang $(26,2 \%)$ sedangkan perempuan sebanyak 79 orang $(73,8 \%)$.

Tabel 2

Distribusi Frekuensi Responden Berdasarkan Pendidikan

\begin{tabular}{ccc}
\hline Pendidikan & Frekuensi & Persentase $(\%)$ \\
\hline Rendah & 77 & 72,0 \\
Tinggi & 30 & 28,0 \\
\hline Total & 107 & 100
\end{tabular}

Berdasarkan tabel 2 diatas menunjukan distribusi responden berdasarkan pendidikan, didapatkan 77 responden (72\%) berpendidikan rendah sedangkan 30 responden (28\%) berpendidikan tinggi.

Tabel 3

Distribusi Frekuensi Responden Berdasarkan Riwayat Penyakit

\begin{tabular}{ccc}
\hline Riwayat Penyakit & Frekuensi & Persentase (\%) \\
Ada & 13 & 12,1 \\
Tidak Ada & 94 & 87,9 \\
\hline Total & 107 & 100 \\
\hline Berdasarkan tabel 3 diatas & menunjukkan distribusi responden berdasarkan riwayat penyakit,
\end{tabular}
didapatkan 13 responden $(12,1 \%)$ memiliki riwayat penyakit, sedangkan 94 responden $(87,9 \%)$ tidak ada riwayat penyakit.

Arti Febriyani Hutasuhut, Program Studi Pendidikan Dokter Universitas Malahayati, email: artifebriyani@gmail.com

Marisa Anggraini, Program Studi Pendidikan Dokter Universitas Malahayati

Reza Angnesti, Program Studi Pendidikan Dokter Universitas Malahayati 
ANALISIS FUNGSI KOGNITIF PADA LANSIA DITINJAU DARI JENIS KELAMIN, RIWAYAT PENDIDIKAN, RIWAYAT PENYAKIT, AKTIVITAS FISIK, AKTIVITAS KOGNITIF, DAN KETERLIBATAN SOSIAL

Tabel 4

Distribusi Frekuensi RespondenBerdasarkan Aktivitas Fisik

\begin{tabular}{ccc}
\hline Aktivitas Fisik & Frekuensi & Persentase (\%) \\
\hline Rendah & 51 & 47,7 \\
Baik & 56 & 52,3 \\
\hline Total & 107 & 100 \\
\hline
\end{tabular}

Berdasarkan tabel 4 diatas menunjukkan distribusi responden berdasarkan aktivitas fisik, didapatkan aktivitas fisik yang rendah berjumlah 51 responden $(47,7 \%)$, sedangkan aktivitas fisik yang baik berjumlah 56 responden (52,3\%). Berdasarkan analisis terhadap jenis aktivitas fisik yang dilakukan lansia, ditemukan bahwa berjalan kaki merupakan aktivitas fisik yang paling dominan pada lansia di wilayah kerja Puskesmas Kedaton Bandar Lampung sedangkan aktivitas fisik yang memiliki nilai terendah adalah olahraga / latihan fisik.

Tabel 5

Distribusi Frekuensi Responden Berdasarkan Aktivitas Kognitif

\begin{tabular}{ccc}
\hline Aktivitas Kognitif & Frekuensi & Persentase (\%) \\
\hline Rendah & 39 & 36,4 \\
Baik & 68 & 63,6 \\
\hline Total & 107 & 100 \\
\hline Berdasarkan & tabel 5 diatas menunjukkan distribusi responden berdasarkan aktivitas kognitif,
\end{tabular}
didapatkan lansia yang aktivitas kognitifnya rendah berjumlah 39 responden $(36,4 \%)$, sedangkan lansia yang aktivitas kognitifnya baik berjumlah 68 responden $(63,6 \%)$. Berdasarkan analisis terhadap jenis-jenis aktivitas kognitif pada lansia, ditemukan bahwa bahwa 3 jenis aktivitas kognitif yang paling banyak dilakukan adalah menonton siaran berita televisi, menonton siaran televisi hiburan/ video film, dan memasak sendiri.

Tabel 6

Distribusi Frekuensi RespondenBerdasarkan Keterlibatan Sosial

\begin{tabular}{|c|c|c|}
\hline Keterlibatan Sosial & Frekuensi & Persentase (\%) \\
\hline Rendah & 20 & 18,7 \\
\hline Baik & 87 & 81,3 \\
\hline Total & 107 & 100 \\
\hline
\end{tabular}

didapatkan lansia yang keterlibatan sosialnya rendah berjumlah 20 responden $(18,7 \%)$, sedangkan lansia yang keterlibatan sosialnya baik berjumlah 87 responden $(81,3 \%)$. Berdasarkan analisis terhadap aspekaspek keterlibatan sosial, ditemukan bahwa aspek keterlibatan sosial yang tertinggi frekuensinya pada

Arti Febriyani Hutasuhut, Program Studi Pendidikan Dokter Universitas Malahayati, email: artifebriyani@gmail.com

Marisa Anggraini, Program Studi Pendidikan Dokter Universitas Malahayati

Reza Angnesti, Program Studi Pendidikan Dokter Universitas Malahayati 


\section{ANALISIS FUNGSI KOGNITIF PADA LANSIA DITINJAU DARI JENIS KELAMIN, RIWAYAT PENDIDIKAN, RIWAYAT PENYAKIT, AKTIVITAS FISIK, AKTIVITAS KOGNITIF, DAN KETERLIBATAN SOSIAL}

lansia di wilayah kerja Puskesmas Kedaton Bandar Lampung dalam penelitian ini adalah kontak visual per bulan dengan 3 atau lebih keluarga dan atau sahabat.

\section{Tabel 7}

Distribusi Frekuensi RespondenBerdasarkan Fungsi Kognitif

\begin{tabular}{lll}
\hline Fungsi Kognitif Lansia & Frekuensi & Persentase (\%) \\
\hline Terganggu & 46 & 43,0 \\
Normal & 61 & 57,0 \\
\hline Total & 107 & 100 \\
\hline & Berdasarkan tabel 7 diatas menunjukkan distribusi responden berdasarkan fungsi kognitif pada
\end{tabular}

lansia wilayah kerja Puskesmas Kedaton Bandar Lampung tahun 2018, didapatkan 46 responden (43,0\%) fungsi kognitifnya terganggu, sedangkan 61 responden $(57,0 \%)$ memiliki fungsi kognitif normal. Berdasarkan analisis terhadap aspek-aspek fungsi kognitif dalam MMSE, ditemukan bahwa fungsi kognitif yang tertinggi adalah menyebutkan nama benda yang ditunjuk (pensil, buku), menyebutkan tiga buah nama benda yang tidak berhubungan (Apel, Meja, Koin), dan menyebutkan tempat (kelurahan, kecamatan, kota, propinsi dan negara), sedangkan yang terendah yaitu menuliskan kalimat tentang sesuatu dengan spontan, mengeja terbalik kata "WAHYU", dan mengulang frase : tidak jika dan, akan tetapi

\section{Analisis Bivariat}

Analisis bivariat merupakan analisis terhadap dua variabel yang diduga berhubungan atau berkorelasi. Analisis bivariat dalam penelitian ini dilakukan untuk mengetahui ada atau tidaknya hubungan antara variabel bebas (jenis kelamin, pendidikan, riwayat penyakit, aktivitas fisik, aktivitas kognitif dan keterlibaatan sosial) dengan variabel terikat (fungsi kognitif).

Arti Febriyani Hutasuhut, Program Studi Pendidikan Dokter Universitas Malahayati, email: artifebriyani@gmail.com

Marisa Anggraini, Program Studi Pendidikan Dokter Universitas Malahayati

Reza Angnesti, Program Studi Pendidikan Dokter Universitas Malahayati 
ANALISIS FUNGSI KOGNITIF PADA LANSIA DITINJAU DARI JENIS KELAMIN, RIWAYAT PENDIDIKAN, RIWAYAT PENYAKIT, AKTIVITAS FISIK, AKTIVITAS KOGNITIF, DAN KETERLIBATAN SOSIAL

Tabel 12

Fungsi Kognitif Berdasarkan Jenis Kelamin, Rlwayat Pendidikan, Riwayat Penyakit, Aktivitas Fisik, Aktivitas Kognitif, dan Keterlibatan Ssial pada Lansia

\begin{tabular}{|c|c|c|c|c|c|c|c|c|}
\hline \multirow{3}{*}{ Variabel } & \multicolumn{4}{|c|}{ Fungsi kogntif } & \multirow{2}{*}{\multicolumn{2}{|c|}{ Total }} & \multirow{3}{*}{$p$-value } & \multirow{3}{*}{$\begin{array}{c}\text { OR } \\
(95 \% \mathrm{Cl})\end{array}$} \\
\hline & \multicolumn{2}{|c|}{ Normal } & \multicolumn{2}{|c|}{ Terganggu } & & & & \\
\hline & $\mathbf{N}$ & $\%$ & $\mathbf{N}$ & $\%$ & $\mathrm{n}$ & $\%$ & & \\
\hline Jenis Kelamin & & & & & & & \multirow{3}{*}{0,383} & \\
\hline Perempuan & 47 & 59,5 & 32 & 40,5 & 79 & 100 & & $\begin{array}{r}0,68 \\
0\end{array}$ \\
\hline Laki-laki & 14 & 50,0 & 14 & 50,0 & 28 & 100 & & $\begin{array}{l}(0,29- \\
1,62)\end{array}$ \\
\hline \multicolumn{8}{|l|}{ Pendidikan } & \\
\hline Rendah & 37 & 48,1 & 40 & 51,9 & 77 & 100 & \multirow{2}{*}{0,003} & $\begin{array}{r}4,32 \\
1159\end{array}$ \\
\hline Tinggi & 24 & 80,0 & 6 & 20,0 & 30 & 100 & & $\begin{array}{l}(1,59- \\
11,76)\end{array}$ \\
\hline \multicolumn{8}{|l|}{ Riwayat Penyakit } & \multirow{3}{*}{$\begin{array}{c}5,37 \\
(1,38- \\
20,82)\end{array}$} \\
\hline Ada & 3 & 23,1 & 10 & 76,9 & 13 & 100 & & \\
\hline Tidak Ada & 58 & 61,7 & 36 & 38,3 & 94 & 100 & 0,008 & \\
\hline \multicolumn{9}{|l|}{ Aktivitas Fisik } \\
\hline Rendah & 20 & 39,2 & 31 & 60,8 & 51 & 100 & \multirow{2}{*}{0,000} & 4,24 \\
\hline Baik & 41 & 73,2 & 15 & 26,8 & 56 & 100 & & $(1,87-9,58)$ \\
\hline \multicolumn{9}{|l|}{ Aktivitas Kognitif } \\
\hline Rendah & 14 & 35,9 & 25 & 64,1 & 39 & 100 & \multirow{2}{*}{0,001} & 3,99 \\
\hline Baik & 47 & 69,1 & 21 & 30,9 & 68 & 100 & & $(1,74-9,19)$ \\
\hline \multicolumn{8}{|l|}{ Keterlibatan Sosial } & \\
\hline Rendah & 5 & 25,0 & 15 & 75,0 & 20 & 100 & \multirow{2}{*}{0,001} & $(1,79$ \\
\hline Baik & 56 & 64,4 & 31 & 35,6 & 87 & 100 & & $\begin{array}{l}(1,19- \\
16,33)\end{array}$ \\
\hline
\end{tabular}

Berdasarkan tabel di atas, ditemukan bahwa untuk jenis kelamin terdapat $28(26,2 \%)$ lansia berjenis kelamin laki-laki dan perempuan sebanyak $79(73,8 \%)$. Hasil uji statistik diperoleh $p$-value 0,383 yang berarti $p>a=0,05$ maka dapat disimpulkan bahwa tidak ada hubungan antara jenis kelamin dengan fungsi kognitif pada lansia. Untuk variabel pendidikan, ditemukan bahwa lansia yang berpendidikan rendah sebanyak $77(72 \%)$ dan pendidikan tinggi sebanyak 30 (28\%). Hasil uji statistik diperoleh $p$-value 0,003 yang berarti $p<a=0,05$ maka dapat disimpulkan bahwa ada hubungan antara pendidikan dengan fungsi kogntif pada lansia, dengan nilai OR 4,324 berarti responden dengan pendidikan rendah memiliki peluang 4 kali lebih besar terhadap gangguan fungsi kognitif. Untuk variabel riwayat penyakit, ditemukan bahwa lansia dengan riwayat penyakit sebanyak $13(12,1 \%)$ dan tidak ada riwayat penyakit sebanyak 94

Arti Febriyani Hutasuhut, Program Studi Pendidikan Dokter Universitas Malahayati, email: artifebriyani@gmail.com

Marisa Anggraini, Program Studi Pendidikan Dokter Universitas Malahayati

Reza Angnesti, Program Studi Pendidikan Dokter Universitas Malahayati 


\section{ANALISIS FUNGSI KOGNITIF PADA LANSIA DITINJAU DARI JENIS KELAMIN, RIWAYAT PENDIDIKAN, RIWAYAT PENYAKIT, AKTIVITAS FISIK, AKTIVITAS KOGNITIF, DAN KETERLIBATAN SOSIAL}

$(87,9 \%)$. Hasil uji statistik diperoleh $p$-value 0,008 yang berarti $p<a=0,05$ maka dapat disimpulkan bahwa ada hubungan antara riwayat penyakit dengan fungsi kogntif pada lansia, dengan nilai OR 5,370 berarti responden dengan riwayat penyakit memiliki peluang 5 kali lebih besar terhadap gangguan fungsi kognitif. Untuk variabel aktivitas fisik ditemukan bahwa ada sebanyak 51 (47,7\%) responden aktivitas fisik rendah dan $56(52,3 \%)$ aktivitas fisiknya baik. Hasil uji statistik diperoleh $p$-value 0,000 yang berarti $p<a=$ 0,05 maka dapat disimpulkan bahwa ada hubungan antara aktivitas fisik dengan fungsi kognitif pada lansia, dengan nilai OR 4,237 berarti responden dengan aktivitas fisik yang rendah memiliki peluang 4 kali lebih besar terhadap gangguan fungsi kognitif. Untuk aktivitas kognitif ditemukan bahwa responden dengan aktivitas kognitif rendah sebanyak $39(36,4 \%)$ dan tidak ada riwayat penyakit sebanyak 68 (63,6\%). Hasil uji statistik diperoleh $p$-value 0,001 yang berarti $p<a=0,05$ maka dapat disimpulkan bahwa ada hubungan antara aktivitas kognitif dengan fungsi kognitif pada lansia, dengan nilai OR 3,997 berarti responden dengan aktivitas kognitif memiliki peluang 3 kali lebih besar terhadap gangguan fungsi kognitif. Untuk keterlibatan sosial, ditemukan bahwa responden dengan keterlibatan sosial rendah sebanyak 20 $(18,7 \%)$ dan sebanyak $87(81,3 \%)$ keterlibatan sosialnya baik. Hasil uji statistik diperoleh $p$-value 0,001 yang berarti $p<\alpha=0,05$, maka dapat disimpulkan bahwa ada hubungan antara keterlibatan sosial dengan fungsi kogntif pada lansia, dengan nilai OR 5,419 berarti responden dengan keterlibatan sosial rendah memiliki peluang 5 kali lebih besar terhadap gangguan fungsi kognitif.

\section{DISKUSI}

\section{a. Hubungan Jenis Kelamin dengan Fungsi Kognitif pada Lansia}

Hasil analisis menunjukkan bahwa tidak ada hubungan antara jenis kelamin dengan fungsi kognitif pada lansia di wilayah kerja Puskesmas Kedaton Bandar Lampung tahun 2018. Hasil penelitian ini didukung oleh penelitian Mardiyanto, Jahja, dan Limyati (2017), dikatakan bahwa tidak ada perbedaan yang signifikan antara laki-laki dan perempuan dalam mempertahankan fungsi kognitif. Pada penelitian-penelitian sebelumnya, terdapat pula temuan yang tidak mendukung temuan penelitian ini. Salah satunya penelitian yang telah dilakukan oleh Yaffe, Barnes, Lindquist, Cauley, Simonsick, Peninx, Satterfield, Harris, Cumming, dan Health ABC Investigators (2007), ditemukan bahwa terdapat hubungan estradiol dengan penurunan kognitif yang lebih kuat pada perempuan dibandingkan laki-laki. Perempuan tampaknya lebih berisiko mengalami penurunan fungsi kognitif disebabkan adanya peranan level hormon seks endogen yaitu esterogen dalam perubahan fungsi kognitif.

Arti Febriyani Hutasuhut, Program Studi Pendidikan Dokter Universitas Malahayati, email: artifebriyani@gmail.com

Marisa Anggraini, Program Studi Pendidikan Dokter Universitas Malahayati

Reza Angnesti, Program Studi Pendidikan Dokter Universitas Malahayati 


\section{ANALISIS FUNGSI KOGNITIF PADA LANSIA DITINJAU DARI JENIS KELAMIN, RIWAYAT PENDIDIKAN, RIWAYAT PENYAKIT, AKTIVITAS FISIK, AKTIVITAS KOGNITIF, DAN KETERLIBATAN SOSIAL}

Selain itu, Lumbantobing (2006) menjelaskan bahwa perempuan mempunyai risiko lebih tinggi dari laki-laki untuk menderita gangguan fungsi kognitif seperti demensia Alzheimer, ini disebabkan karena umur wanita lebih panjang dari pria, sedangkan pria memiliki risiko yang lebih tinggi untuk mengalami demensia vaskuler. Hal ini diperkirakan karena pria lebih cenderung melakukan kebiasaankebiasaan yang dapat memicu terjadinya gangguan vaskular seperti merokok dan mengkonsumsi alkohol.

Adanya perbedaan hasil penelitian ini dengan temuan-temuan sebelumnya dapat berhubungan dengan tidak seimbanganya perbandingan antara sampel perempuan dan laki-laki, serta adanya faktor lainnya seperti pendidikan, aktivitas fisik, aktivitas kognitif, dan keterlibatan sosial yang juga dapat mempengaruhi sehingga lansia lebih daapat mempertaahankan fungsi kognitifnya.

\section{b. Hubungan Pendidikan dengan Fungsi Kognitif pada Lansia}

Dari hasil penelitian didapatkan ada hubungan signifikan antara pendidikan dengan fungsi kogntif pada lansia di wilayah kerja Puskesmas Kedaton Bandar Lampung tahun 2018, dimana responden dengan pendidikan rendah memiliki peluang 4 kali lebih besar terhadap gangguan fungsi kognitif.
Hal ini sesuai dengan pernyataan Ngandu (2007), bahwa seseorang yang memiliki tingkat pendidikan tinggi memiliki faktor pelindung dari risiko terkena gangguan fungsi kognitif yaitu demensia. Hasil penelitian ini juga selaras dengan penelitian Mardiyanto, Jahja, dan Limyati (2017) yang meneliti faktor-faktor yang berhubungan dengan fungsi kognitif pada populasi lansia dimana didapatkan hubungan yang signifikan antara pendidikan dan fungsi kognitif dengan $p$-value 0,000.

Suatu studi yang dilakukan oleh Bennet, Wilson, Scneider, Evans, De Leon, Arnold, Barnes, dan Bienias (2003) untuk mengetahui hubungan tingkat edukasi formal dan patologi penyakit Alzheimer ternyata dijumpai adanya bukti kuat antara senile plaque dan level fungsi kognitif yang berbeda berdasarkan tingkat edukasi formal. Pada penelitian yang dilakukan oleh Paddick, Longdon, Gray, Dotchin, Kisoli, Chaote, dan Walker (2014), didapatkan hubungan yang signifikan antara tingkat pendidikan yang rendah dengan demensia pada populasi di pedesaan Tanzania. Pendapat ini dipertegas penelitian meta analitik yang dilakukan oleh Francisco seperti yang dikutip oleh Mardiyanto, Jahja, dan Limyati (2017), yang menyimpulkan bahwa tingkat pendidikan seseorang merupakan faktor risiko terjadinya demensia terutama penyakit Alzheimer.

Arti Febriyani Hutasuhut, Program Studi Pendidikan Dokter Universitas Malahayati, email: artifebriyani@gmail.com

Marisa Anggraini, Program Studi Pendidikan Dokter Universitas Malahayati

Reza Angnesti, Program Studi Pendidikan Dokter Universitas Malahayati 


\section{ANALISIS FUNGSI KOGNITIF PADA LANSIA DITINJAU DARI JENIS KELAMIN, RIWAYAT PENDIDIKAN, RIWAYAT PENYAKIT, AKTIVITAS FISIK, AKTIVITAS KOGNITIF, DAN KETERLIBATAN SOSIAL}

Semakin rendah tingkat pendidikan semakin tinggi angka prevalensi demensia Alzheimer.

Hipotesis cognitive reserve dapat menjelaskan hubungan pendidikan dengan fungsi kognitif. Hipotesis ini menjelaskan bahwa ada perbedaan individu dalam kemampuan untuk mentoleransi perubahan patologi di otak terkait usia. Pendidikan dapat meningkatkan cognitive reserve sehingga penyakit Alzheimer pada tingkat pendidikan tinggi baru bermanifestasi secara klinis setelah kelainan patologi otak cukup parah (patologis di otak yang berpendidikan tinggi lebih berat dari yang berpendidikan rendah saat penyakit Alzheimer terdeteksi). Cognitive reserve menjelaskan hubungan antara pendidikan, kompleksitas pekerjaan, kemampuan membaca, Intellegence Quotient (IQ) dan demensia. Cadangan ini terlihat sebagai hasil dari perubahan otak itu sendiri yang dihasilkan dari perubahan dalam struktur dan pemrosesan otak (Meng \& D'Arcy, 2012).

Menurut Murray et al seperti yang dikutip oleh Paddick, Longdon, Gray, Dotchin, Kisoli, Chaote, dan Walker (2014), pendidikan diperkirakan meningkatkan cadangan kognitif melalui neuroplastisitas dan penciptaan jaringan saraf yang lebih kompleks sehingga mampu mengkompensasi tingkat neuropatologi yang lebih besar di kemudian hari.

\section{Hubungan Riwayat Penyakit dengan Fungsi Kognitif pada Lansia}

Dari hasil penelitian didapatkan ada hubungan yang signifikan antara riwayat penyakit dengan fungsi kogntif pada lansia di wilayah kerja Puskesmas Kedaton Bandar Lampung tahun 2018, dimana lansia dengan riwayat penyakit memiliki peluang 5 kali lebih besar terhadap gangguan fungsi kognitif.

Hasil penelitian ini sesuai dengan penelitian Putri, Mutiawati, dan Mahdani (2017), dimana didapatkan hubungan antara derajat stroke dengan status fungsi kognitif dengan $p$-value 0,000. Menurut Kaplan dan Saddock seperti yang dikutip oleh Riyanto dan Brahmadhi (2017), gangguan kognitif yang terjadi pasca serangan stroke diklasifikasikan ke dalam demensia vaskular. Riwayat penyakit seperti hipertensi dan diabetes diketahui memberikan kontribusi yang besar terhadap meningkatnya derajat stroke. Gangguan terutama mengenai pembuluh darah serebral berukuran kecil dan sedang, yang mengalami infark dan menghasilkan lesi parenkim multipel yang menyebar pada daerah otak yang luas. Penyebab infark mungkin termasuk oklusi pembuluh darah oleh plak aterioklerotik atau tromboemboli dari tempat asal yang jauh (Sadock \& Sadock, 2011)

Stroke merupakan suatu penyakit
serebrovaskular akibat penurunan atau

Arti Febriyani Hutasuhut, Program Studi Pendidikan Dokter Universitas Malahayati, email: artifebriyani@gmail.com

Marisa Anggraini, Program Studi Pendidikan Dokter Universitas Malahayati

Reza Angnesti, Program Studi Pendidikan Dokter Universitas Malahayati 


\section{ANALISIS FUNGSI KOGNITIF PADA LANSIA DITINJAU DARI JENIS KELAMIN, RIWAYAT PENDIDIKAN, RIWAYAT PENYAKIT, AKTIVITAS FISIK, AKTIVITAS KOGNITIF, DAN KETERLIBATAN SOSIAL}

terhentinya aliran darah ke otak. Peningkatan frekuensi stroke terjadi seiring dengan peningkatan umur berhubungan dengan proses penuaan, dimana semua organ tubuh mengalami kemunduran fungsi termasuk pembuluh darah otak. Pembuluh darah menjadi tidak elastis terutama pada bagian endotel yang mengalami penebalan di bagian intima, sehingga mengakibatkan lumen pembuluh darah semakin sempit dan berakibat pada penurunan aliran darah otak (Putri, Mutiawati, dan Mahdani, 2017).

Perkembangan stroke menjadi demensia dipengaruhi beberapa faktor termasuk lokasi dan volume stroke, tingkat kerusakan neuronal terkait adanya gangguan kognitif yang sudah ada sebelumnya atau patologi otak lainnya (Kalaria, Akinyemi, dan Ihara 2016). Pada saat stroke terjadi kerusakan sel-sel otak sehingga menyebabkan kecacatan fungsi sensoris, motoris, maupun kognitif.

\section{d. Hubungan Aktivitas Fisik dengan Fungsi Kognitif pada Lansia}

Dari hasil penelitian didapatkan ada hubungan yang signifikan antara aktivitas fisik dengan fungsi kognitif pada lansia di wilayah kerja Puskesmas Kedaton Bandar Lampung tahun 2018, dimana responden dengan aktivitas fisik yang rendah memiliki peluang 4 kali lebih besar terhadap gangguan fungsi kognitif.
Hasil penelitian ini sejalan dengan penelitian yang dilakukan oleh Muzamil, Afriwardi, dan Martini (2014), yang meneliti hubungan antara tingkat aktivitas fisik dengan fungsi kognitif pada usia lanjut di Kelurahan Jati Kecamatan Padang timur dimana didapatkan hubungan antara tingkat aktivitas fisik dengan fungsi kognitif $(p=0,044)$. Suatu penelitian meta analitik yang dilakukan oleh Groot, Hooghiemstra, Raijmakers, Van Berckel, Scheltens, Scherder, Van der Flier, dan Ossenkoppele (2015), didapatkan efek positif intervensi aktivitas fisik pada fungsi kognitif pasien demensia. Dalam suatu studi yang dilakukan di Manhattan Utara, diketahui bahwa aktivitas fisik waktu luang dihubungkan dengan fungsi kognitif melalui dua mekanisme yaitu vaskular dan nonvaskular. Aktivitas fisik mengurangi kejadian hipertensi dan diabetes serta memperbaiki kerusakan organ termasuk penyakit serebrovaskular subklinis pada orang yang telah menderita penyakit. Aktivitas fisik dikaitan dengan risiko yang lebih rendah terhadap infark otak yang berhubungan dengan fungsi kognitif. (Willey, Gardener, Caunca, Moon, Dong, Cheung, Sacco, Elkind, dan Wright, 2016)

Aktivitas fisik berperan dalam mempertahankan fungsi kognitif melalui tiga mekanisme, yaitu angiogenesis pada otak, perubahan synaptic reverse, dan

Arti Febriyani Hutasuhut, Program Studi Pendidikan Dokter Universitas Malahayati, email: artifebriyani@gmail.com

Marisa Anggraini, Program Studi Pendidikan Dokter Universitas Malahayati

Reza Angnesti, Program Studi Pendidikan Dokter Universitas Malahayati 


\section{ANALISIS FUNGSI KOGNITIF PADA LANSIA DITINJAU DARI JENIS KELAMIN, RIWAYAT PENDIDIKAN, RIWAYAT PENYAKIT, AKTIVITAS FISIK, AKTIVITAS KOGNITIF, DAN KETERLIBATAN SOSIAL}

menghilangkan penumpukan amiloid. Mekanisme yang menjelaskan hubungan antara aktivitas fisik dengan fungsi kognitif seperti regulasi tekanan darah, meningkatkan kadar lipoprotein dan produksi endhotelial nitric oxide, dan menjamin perfusi jaringan otak yang adekuat. Efek langsung terhadap otak yaitu memelihara sruktur saraf serta meningkatkan perluasan serabut saraf, sinap-sinap, dan kapilaris (Weuve, Kang, Manson, Breteler, Ware, Grodstein, 2004).

Aktivitas fisik dapat meningkatkan neurogenesis dan faktor neurotrofik BDNF yang merupakan protein yang ditemukan dalam konsentrasi tinggi di sistem saraf pusat terutama di hipokampus, korteks serebral, hipotalamus dan serebellum. BDNF terlibat dalam pengembangan dari fungsi saraf termasuk neurogenesis, pertumbuhan dendritik dan potensiasi neuron jangka panjang (Szuhany, Bugatti, dan Otto 2014).

Dapat disimpulkan bahwa aktivitas fisik dapat mempertahankan aliran darah yang optimal dan juga meningkatkan penghantaran nutrisi ke otak. Selain itu aktivitas fisik juga memfasilitasi metabolisme neurotransmiter, menghasilkan faktor tropik yang merangsang proses neurogenesis, meningkatkan stimulasi aktivitas molekuler dan seluler di otak yang nantinya mendukung dan menjaga plastisitas otak. Proses-proses ini penting untuk menghambat hipertrofi jaringan otak yang dapat menyebabkan degenerasi neuronal yang berdampak terhadap kognitif (Muzamil, Afriwardi, dan Martini 2014).

\section{e. Hubungan Aktivitas Kognitif dengan Fungsi Kognitif pada Lansia}

Dari hasil penelitian didapatkan ada hubungan yang signifikan antara aktivitas kognitif dengan fungsi kognitif pada lansia di wilayah kerja Puskesmas Kedaton Bandar Lampung tahun 2018, dimana responden dengan aktivitas kognitif memiliki peluang 3 kali lebih besar terhadap gangguan fungsi kognitif.

Hasil penelitian ini didukung oleh penelitian yang dilakukan Wreksoatmodjo (2015), yang dilakukan pada 286 orang lansia di Jakarta. Wilson, Segawa, Boyle, dan Bennet (2012) yang menganalisis data 1076 responden juga menyimpulkan bahwa tingkat partisipasi aktivitas kognitif mempengaruhi tingkat penurunan fungsi kognitif.

Aktivitas kognitif adalah aktivitas yang melibatkan dan atau memerlukan kemampuan berpikir. Dalam penelitian ini, aktivitas yang ditanyakan diantaranya seperti masak sendiri, mengerjakan hobi, membaca buku, majalah dan koran, menonton siaran televisi berita, menonton siaran televisi hiburan atau video film serta main bermain catur, halma, teka-teki silang

Arti Febriyani Hutasuhut, Program Studi Pendidikan Dokter Universitas Malahayati, email: artifebriyani@gmail.com

Marisa Anggraini, Program Studi Pendidikan Dokter Universitas Malahayati

Reza Angnesti, Program Studi Pendidikan Dokter Universitas Malahayati 


\section{ANALISIS FUNGSI KOGNITIF PADA LANSIA DITINJAU DARI JENIS KELAMIN, RIWAYAT PENDIDIKAN, RIWAYAT PENYAKIT, AKTIVITAS FISIK, AKTIVITAS KOGNITIF, DAN KETERLIBATAN SOSIAL}

atau sudoku teratur. Aktivitas kognitif dianggap dapat memelihara cognitive reserve.

Cognitive reserve berhubungan dengan konsep plastisitas otak. Plastisitas otak adalah kemampuan otak untuk mengatur ulang struktur serta koneksi antar neuron yang merujuk pada peningkatan kapasitas otak. Konsep cognitive reserve mengacu pada kemampuan otak untuk mentoleransi patologi perubahan terkait usia (Fratiglioni \& Wang, 2007). Hal ini dipertegas oleh penelitian yang dilakukan Treiber, Carlson, Corcoran, Norton, Breitner, Piercy, De Berard, dan Frye (2011), bahwa aktivitas kognitif di awal perjalanan demensia Alzheimer dikaitkan dengan penurunan kognitif yang lebih lambat.

Aktivitas kognitif merupakan aktivitas yang menstimulasi mental yang secara selektif meningkatkan sinaptogenesis di masa dewasa (Fratiglioni \& Wang, 2007). Aktivitas kognitif dapat menghasilkan reorganisasi jaringan neurokognitif, menekan efek merugikan dari hormon stres ke otak. Terlibat dalam aktivitas kognitif dapat memperbaiki kompensasi otak terhadap patologi dengan cara meningkatkan cadangan otak. Studi pada tikus menunjukkan bahwa aktivitas mental merangsang neurogenesis dan sinaptogenesis, meningkatkan reaktivitas sinaps hipokampus, memperbaiki vaskularisasi otak dan mengurangi deposisi beta amiloid di otak (Wreksoatmodjo, 2015).

\section{f. Hubungan Keterlibatan Sosial dengan Fungsi Kognitif pada Lansia}

Dari hasil penelitian didapatkan ada hubungan yang signifikan antara keterlibatan sosial dengan fungsi kogntif pada lansia di wilayah kerja Puskesmas Kedaton Bandar Lampung tahun 2018, dimana responden dengan keterlibatan sosial rendah memiliki peluang 5 kali lebih besar terhadap gangguan fungsi kognitif.

Penelitian ini didukung oleh penelitian yang dilakukan Budi Riyanto Wreksoatmodjo (2014), didapatkan bahwa ada hubungan bermakna antara keterlibatan sosial dengan fungsi kognitif. Lansia dengan keterlibatan sosial yang buruk memiliki risiko dua kali lebih besar untuk mempunyai fungsi kognitif buruk dibandingkan lansia dengan keterlibatan sosial yang baik. Keterlibatan sosial atau social engagement diartikan sebagai kemampuan memelihara hubungan sosial (jaringan sosial) dan berpartisipasi dalam kegiatan sosial (aktivitas sosial) (Bassuk, Glass, dan Berkman, 1999).

Pada suatu studi meta analitik yang dilakukan oleh Kuiper, Zuidersma, Voshaar, Zuidema, Van den Heuvel, Stolk, dan Smidt (2015) menunjukkan bahwa orang dengan partisipasi sosial yang kurang, kontak sosial yang jarang dan lebih banyak merasakan kesepian memiliki risiko demensia. Bassuk, Glass, dan Berkman (1999) menemukan

Arti Febriyani Hutasuhut, Program Studi Pendidikan Dokter Universitas Malahayati, email: artifebriyani@gmail.com

Marisa Anggraini, Program Studi Pendidikan Dokter Universitas Malahayati

Reza Angnesti, Program Studi Pendidikan Dokter Universitas Malahayati 


\section{ANALISIS FUNGSI KOGNITIF PADA LANSIA DITINJAU DARI JENIS KELAMIN, RIWAYAT PENDIDIKAN, RIWAYAT PENYAKIT, AKTIVITAS FISIK, AKTIVITAS KOGNITIF, DAN KETERLIBATAN SOSIAL}

hubungan antara keterlibatan sosial dan penurunan fungsi kognitif pada usia lanjut yang tinggal di keluarga.

Menurut Ho seperti yang dikutip oleh Wreksoatmodjo (2014), keterlibatan sosial dianggap dapat memelihara fungsi kognitif melalui mekanisme scaffolding berupa pengaktifan jaringan tambahan sehingga jaringan otak menjadi lebih efisien; makin banyak jaringan tambahan yang tersedia, akan makin efisien mekanisme kompensatorik tadi, dan stimulasi lingkungan telah terbukti bisa menambah tersedianya jaringan tambahan tersebut. Keterlibatan sosial melibatkan fungsi kognisi sosial. Kognisi sosial didukung oleh jaringan ekstensif yang melibatkan sistem limbik dan area asosiasi kortikal maupun subkortikal. Daerah-daerah tersebut juga mendukung memori episodik, memori semantik dan fungsi kognitif lainnya (Wreksoatmodjo, 2014).

Penjelasan potensial lainnya mengapa keterlibatan sosial berhubungan dengan fungsi kognitif berkaitan dengan teori "use or lose if" yang menunjukkan bahwa keterlibatan dalam aktivitas intelektual, sosial dan fisik dapat menstimulasi otak. Penurunan dalam aktivitas sehari-hari termasuk aktivitas sosial dapat berakibat terhadap penurunan penggunaan otak dan berhubungan dengan atrofi pada area fungsi kognitif. Stimulasi lingkungan dan keterlibatan sosial dikaitkan juga dengan neurogenesis, dan peningkatan kepadatan sinaps (Kuiper, Zuidersma, Voshaar, Zuidema, Van den Heuvel, Stolk, dan Smidt, 2015)

Keterlibatan sosial yang rendah juga dikaitkan dengan stres yang dihubungkan dengan dua kali peningkatan risiko demensia Alzheimer karena perubahan struktur hipokampus (Kuiper, Zuidersma, Voshaar, Zuidema, Van den Heuvel, Stolk, dan Smidt, 2015). Menurut Rosita seperti yang dikutip oleh Mardiyanto, Jahja, dan Limyati (2017), semakin banyak hubungan dan aktivitas sosial diasosiasikan dengan semakin lambatnya penurunan kognitif dan mereka yang menerima dukungan emosional mempunyai fungsi kognitif lebih baik. Sebaliknya seseorang yang tidak berinteraksi sosial dengan baik dan tidak mampu beradaptasi dengan perubahan sosial akan menimbulkan reaksi stres dimulai dengan meningkatnya produksi glukokortikoid dan ini berpengaruh terhadap hipotalamus selanjutnya secara perlahan akan mempengaruhi fungsi kognitif.

Keterlibatan sosial dapat menurunkan risiko demensia karena lingkungan sosial dapat memotivasi untuk berperilaku yang sehat dan menghasilkan berbagai sumber informasi yang dapat membantu pemanfaatan sumber daya kesehatan yang tersedia secara efektif (Kuiper, Zuidersma, Voshaar, Zuidema, Van den Heuvel, Stolk, dan Smidt, 2015). Terdapat beberapa

Arti Febriyani Hutasuhut, Program Studi Pendidikan Dokter Universitas Malahayati, email: artifebriyani@gmail.com

Marisa Anggraini, Program Studi Pendidikan Dokter Universitas Malahayati

Reza Angnesti, Program Studi Pendidikan Dokter Universitas Malahayati 


\section{ANALISIS FUNGSI KOGNITIF PADA LANSIA DITINJAU DARI JENIS KELAMIN, RIWAYAT PENDIDIKAN, RIWAYAT PENYAKIT, AKTIVITAS FISIK, AKTIVITAS KOGNITIF, DAN KETERLIBATAN SOSIAL}

alasan mengapa aktivitas sosial dalam bentuk apapun berhubungan dengan fungsi kognitif pada lansia; diantaranya bahwa aktivitas tersebut juga memperbaiki kondisi kesehatan umum dan memperbaiki kesehatan mental.

\section{SIMPULAN DAN SARAN}

Berdasarkan hasil penelitian, dapat disimpulkan bahwa pendidikan, riwayat penyakit, aktivitas fisik, aktivitas kognitif dan keterlibatan sosial berhubungan secara signifikan dengan fungsi kognitif pada lansia di wilayah kerja Puskesmas Kedaton Bandar Lampung tahun 2018, sedangkan jenis kelamin tidak berhubungan dengan fungsi kognitif. Disarankan kepada lansia untuk tetap mempertahankan aktivitas fisik serta kegiatan lainnya yang dapat mempertahankan fungsi kognitif. Puskesmas diharapkan dapat mengembangkan lebih lanjut program program yang melibatkan lansia serta memberikan perhatian lebih terhadap fungsi kognitif lansia. Peneliti selanjutnya diharapkan dapat meneliti lebih lanjut terkait riwayat penyakit lainnya yang dapat mempengaruhi fungsi kognitif.

\section{DAFTAR PUSTAKA}

Bassuk, S. S., Glass, T. A., \& Berkman, L. F. (1999). Social disengagement and incident cognitive decline in community-dwelling elderly persons. Annals of internal medicine, 131(3), 165-173.
Bennett, D. A., Wilson, R. S., Schneider, J. A., Evans, D. A., De Leon, C. M., Arnold, S. E., Barnes, L.L \& Bienias, J. L. (2003). Education modifies the relation of $A D$ pathology to level of cognitive function in older persons. Neurology, 60(12), 19091915.

Fratiglioni, L., \& Wang, H. X. (2007). Brain reserve hypothesis in dementia. Journal of Alzheimer's disease, 12(1), 11-22.

Groot, C., Hooghiemstra, A. M., Raijmakers, P. G. H. M., Van Berckel, B. N. M., Scheltens, P., Scherder, E. J. A., Van der Flier, W.M., \& Ossenkoppele, R. (2016). The effect of physical activity on cognitive function in patients with dementia: a meta-analysis of randomized control trials. Ageing research reviews, 25, 13-23.

Kalaria, R. N., Akinyemi, R., \& Ihara, M. (2016). Stroke injury, cognitive impairment and vascular dementia. Biochimica et Biophysica Acta (BBA)-Molecular Basis of Disease, 1862(5), 915-925.

Kemenkes RI. (2016). INFODATIN Pusat Data dan Informasi Kementerian Kesehatan RI Situasi Lanjut Usia (Lansia) di Indonesia.

Kuiper, J. S., Zuidersma, M., Voshaar, R. C. O., Zuidema, S. U., van den Heuvel, E. R., Stolk, R. P., \& Smidt, N. (2015). Social relationships and risk of dementia: A systematic review and meta-analysis of longitudinal cohort studies. Ageing research reviews, 22, 39-57.

Lumbantobing, S. M. (2006). Kecerdasan Pada Usia Lanjut dan Demensia Edisi 4.

Mardiyanto, F.Y.D., Jahja, D.S., \& Limyati, Y. (2017). Faktor - Faktor yang Berhubungan dengan Fungsi Kognitif pada Populasi Lansia. Journal of Medicine and Health. 1(6), 511-15.

Arti Febriyani Hutasuhut, Program Studi Pendidikan Dokter Universitas Malahayati, email: artifebriyani@gmail.com

Marisa Anggraini, Program Studi Pendidikan Dokter Universitas Malahayati

Reza Angnesti, Program Studi Pendidikan Dokter Universitas Malahayati 


\section{ANALISIS FUNGSI KOGNITIF PADA LANSIA DITINJAU DARI JENIS KELAMIN, RIWAYAT PENDIDIKAN, RIWAYAT PENYAKIT, AKTIVITAS FISIK, AKTIVITAS KOGNITIF, DAN KETERLIBATAN SOSIAL}

Meng, X., \& D'arcy, C. (2012). Education and dementia in the context of the cognitive reserve hypothesis: a systematic review with meta-analyses and qualitative analyses. PloS one, 7(6).

Muzamil, M. S., Afriwardi, A., \& Martini, R. D. (2014). Hubungan antara tingkat aktivitas fisik dengan fungsi kognitif pada usila di Kelurahan Jati Kecamatan Padang Timur. Jurnal Kesehatan Andalas, 3(2).

Ngandu, T., von Strauss, E., Helkala, E. L., Winblad, B., Nissinen, A., Tuomilehto, J., H. Soininen, \& Kivipelto, M. (2007). Education and dementia: what lies behind the association?. Neurology, 69(14), 14421450.

Notoatmodjo, S. (2012). Metodologi penelitian kesehatan (Cetakan VI). Jakarta: Penerbit PT. Rineka Cipta.

Paddick, S. M., Longdon, A., Gray, W. K., Dotchin, C., Kisoli, A., Chaote, P., \& Walker, R. (2014). The association between educational level and dementia in rural Tanzania. Dementia \& neuropsychologia, 8(2), 117-125.

Putri, M. N., Mutiawati, E., \& Mahdani, W. (2017). Hubungan Derajat Stroke Terhadap Status Kognitif Pada Pasien Stroke Iskemik Di Poliklinik Saraf Rumah Sakit Umum Daerah dr. Zainoel Abidin Banda Aceh. Jurnal IImiah Mahasiswa Kedokteran Medisia, 2(1).

Riyanto, R., \& Brahmadhi, A. (2017). Pengaruh Subtype Stroke terhadap Terjadinya Demensia Vascular Pada Pasien Post Stroke di RSUD Prof. Dr. Margono Soekarjo. MEDISAINS, 15(1), 23-30.
Sadock, B. J., \& Sadock, V. A. (2011). Kaplan and Sadock's synopsis of psychiatry: Behavioral sciences/dlinical psychiatry. Lippincott Williams \& Wilkins.

Szuhany, K. L., Bugatti, M., \& Otto, M. W. (2015). A meta-analytic review of the effects of exercise on brain-derived neurotrophic factor. Journal of psychiatric research, 60 , 56-64.

Treiber, K. A., Carlson, M. C., Corcoran, C., Norton, M. C., Breitner, J. C., Piercy, K. W., DeBerard, M.S., Stein, D., Foley, B., WelshBohmer, K.A., \& Frye, A. (2011). Cognitive stimulation and cognitive and functional decline in Alzheimer's disease: the Cache County Dementia Progression Study. Journals of Gerontology Series B: Psychological Sciences and Social Sciences, 66(4), 416-425.

Weuve, J., Kang, J. H., Manson, J. E., Breteler, M. M., Ware, J. H., \& Grodstein, F. (2004). Physical activity, including walking, and cognitive function in older women. Jama, 292(12), 1454-1461.

Willey, J. Z., Gardener, H., Caunca, M. R., Moon, Y. P., Dong, C., Cheung, Y. K., Sacco, R.L., Elkind, M.S, \& Wright, C. B. (2016). Leisure-time physical activity associates with cognitive decline: The Northern Manhattan Study. Neurology, 86(20), 1897-1903.

Wilson, R. S., Segawa, E., Boyle, P. A., \& Bennett, D. A. (2012). Influence of late-life cognitive activity on cognitive health. Neurology, 78(15), 1123-1129.

Wreksoatmodjo, B. R. (2014). Analisis Komponen Aktivitas dan Jaringan Sosial yang Berpengaruh terhadap Fungsi Kognitif Lanjut Usia. Majalah Cermin Dunia Kedokteran, 41(8), 579.

Arti Febriyani Hutasuhut, Program Studi Pendidikan Dokter Universitas Malahayati, email: artifebriyani@gmail.com

Marisa Anggraini, Program Studi Pendidikan Dokter Universitas Malahayati

Reza Angnesti, Program Studi Pendidikan Dokter Universitas Malahayati 


\section{ANALISIS FUNGSI KOGNITIF PADA LANSIA DITINJAU DARI JENIS KELAMIN, RIWAYAT PENDIDIKAN, RIWAYAT PENYAKIT, AKTIVITAS FISIK, AKTIVITAS KOGNITIF, DAN KETERLIBATAN SOSIAL}

Wreksoatmodjo, B.R. (2015). Aktivitas kognitif mempengaruhi fungsi kognitif lanjut usia di Jakarta. CDK-224, 42(1), 8.

Wreksoatmodjo, B. R. (2016). Pengaruh Aktivitas Fisik terhadap Fungsi Kognitif Lanjut Usia di Jakarta Barat. Cermin Dunia Kedokteran, 43(1), 07-12.
Yaffe, K., Barnes, D., Lindquist, K., Cauley, J., Simonsick, E. M., Penninx, B., S. Satterfield, T. Harris, S. R. Cummings, \& Health ABC Investigators. (2007). Endogenous sex hormone levels and risk of cognitive decline in an older biracial cohort. Neurobiology of aging, 28(2), 171-178.

Arti Febriyani Hutasuhut, Program Studi Pendidikan Dokter Universitas Malahayati, email: artifebriyani@gmail.com

Marisa Anggraini, Program Studi Pendidikan Dokter Universitas Malahayati

Reza Angnesti, Program Studi Pendidikan Dokter Universitas Malahayati 